UNITED STATES DEPARTMENT OF THE INTERIOR

GEOLOGICAL SURVEY

FAST-ICE THICKNESS AND SNOW DEPTH LN RELATION TO OIL

TN TRAPMENT POTENTIAL, PRUDHOE BAY, ALASKA
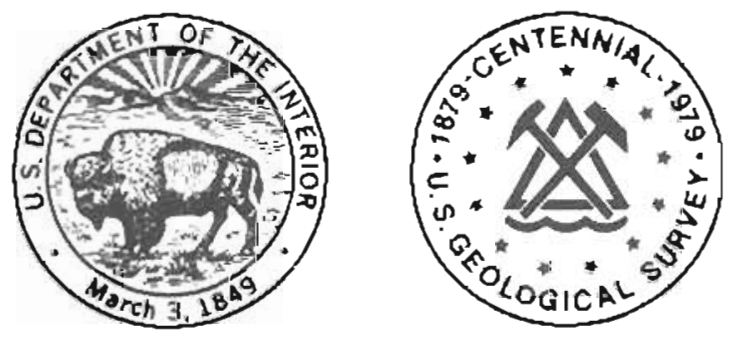

OPEN-FILE REPORT 79.539

This report is preliminary and has not been edited or reviswed for conformity with Geological Survey standards and nomenclature

Menlo Park, California 

UNITED STATES

DEPARTMENT OF THE INTERIOR

GEOLOGICAL SURVEY

FAST-ICE THICKNESS AND SNOW DEPTH IN

RELATION TO OIL ENTRAPMENT POTENTIAL,

PRUDHOE BAY, ALASKA

By peter $W$. Barnes, Erk Reimnitz, Lawrence J. Toimil, and Harry R. Hill

Open-File Report 79-539

Menlo Park, California

March 1979 



\section{Fast-ice Thickness and Snow Depth in Relation to oil \\ Entrapment Potential, Frudhoe Bay, Alaska}

Peter $W$. Barnes, Erk Reimnitz, Lawrence J. Toimil, and Harry R. Hill

$$
\text { ABSTRACT }
$$

In winter, the undersurface of the sea ice on shallow arctic shelves acts upon the sea bed directly by contact and indirectly by influencing currents and turbulence. The under-ice surface would serve as a trap for pollutants : ilcl in oil and gas released from the sea bed. A knowledge of the morpiology of the undersurface of the ice is a first step in understandilly the sea-bed interactions and in evaluating the quantities, configuration, and dispersal patterns of sub-ice pollutants. Investigations show thicker sea-ice correlates with a thin snow cover and thin sea-ice underiles elongate snow ridges.

In early May, 1978, the relationships between under-ice morphology, sea bed morphology, tidal currents, and variations in snow thickness were studied. At three sites representing three different environments--protected bay, deep, open lagoon, and narrow tidal channel--trenches were cut through the ice. The trenches were parallel and perpendicular to the sastrugi-sculptured northeast-southwest trending snow ridge pattern. Snow depth, ice thickness, and ice drafts were measured and an upward-directed side-scanning sonar was towed to examine the moxphology of the under-ice surface in an area $100 \mathrm{~m}$ square. Snow depth and ice thickness vary about $30-40 \mathrm{~cm}$ and exhibit a negative correlation--thin ice coinciding with a thicker insulating snow cover. The areal snow and ice morphology patterns reinforced the correlation. Elongate ridge and trough patterns on the under-ice 
surface parallel the surface snow ridge patterns on wavelengths typically $10 \mathrm{~m}$ wide, yielding sub-ice voids of 25 to $47 \mathrm{k} 10^{3} \mathrm{~m}^{3} / \mathrm{km}^{2}$ (600-1200 barrels per acre). Diving observations indicate a smaller set of depressions $5 \mathrm{~cm}$ or less in depth, oriented parallel to the ice crystal fabric, and an escape of sub-ice released air to the snow-ice interface.

The results imply that there is a seasonal stability to the snow ridge pattern and that oil concentrations under the ice would be indicated by surficial snow morphology in the fast ice zone. Spreading directions would be enlianced in the elongate dimensions of the under-ice ridges and troughs, that is, upwind and dowwind. In spring, gases will leak to the surface.

\section{INTRODUCTION}

The undersurface of sea ice on arctic shelves interacts with the sea bed directly and indirectly by the disruptive processes associated with ice gouging and by influencing currents and twrbrlence. Furthermore, the under-ice surface serves as a trap for Eloatiny pollutants released from the sea bed in winter. A knowledge of the morphology of the undersurface of the ice is a first step in understanding the sea-bed interactions and in evaluatina the quantities, configuration, and dispersal patterns of sub-ice pollutants.

In this report we discuss the three-dimensional morphology of sea ice at three sites on the fast ice in the prudhoe Bay area. At each of the sites - protected bay, open lagoon, and tidal channel - snow depth and ice thickness show a negative correlation, reflecting the insulation of the ice by snow and a seasonal stability to the snow ridge patterns on the seamice surface. 
Backeround

\section{Ice Environment}

The studies which fom the basis of this report were all conducted in the fast-ice zone. This ice zone is a seasonal ice formation which is essentially immobile in winter, forming an extension of the land surface (Kovacs and Mellor, 1974, p. 116). Depending on the snow cover and local temperature regime, fast-ice growth is initiated in september or October, growing at a rate of about $1 \mathrm{~cm}$ per day, reaching

thicknesses of $2 \mathrm{~m}$ by the end of the growth season in March or April (Kovacs and Mellor, ibid; Schell, 1974, p. 231). Seaward extent of fast ice is controlled by watex depth, the protection afforded ice by the shoreline, the time available for growth of the fast ice, and the magnitude and intensity of pack ice movement on the inner shelf (kovacs and Mellor, p. 117). The character of the fast ice is affected by atmospheric and oceanographic conditions at the time of freezing. Currents, waves, and winds at the time of freezing cause the initial fast-ice surface to be rough whereas calm conditions during freeze-up cause a smooth surface (Kovacs and Mellor, ibid). Early winter storms can also disiodge and reorient sections of the fast ice if the ice has not yet achieved sufficient strength to withstand these forces.

\section{Snow Cover}

Benson and his coworkexs (1975, p. 13) have noted that the snow cover along the arctic coast of Blaska is similar to that of Greenland and Antarctica, being characterized as hard, high density, wind-packed snow, overlying a low density snow. These workers also note that wind drifts are formed in response to the prevailing northeasterlies. In the 
ral1, at wind speeds of 12 to $20 \mathrm{~m}$ per second, snow ridges form as stationary features parallel to prevailing winds--30 to $60 \mathrm{~m}$ long, 10 to $20 \mathrm{~cm}$ high, and 6 to $8 \mathrm{~m}$ wide (Kruchinin, 1962). Snow ridges are subsequently scoured, forming steep-faced erosional features called sastrugi which are common through the remainder of the winter. Eroded snow together with additional precipitation form snow spots, irregularly shaped patches of soft snow approximately $10 \mathrm{~m}$ in diameter and $10 \mathrm{~cm}$ deep, or snow barchans which move under the influence of the prevailing winds across the more stable snow ridges (Kruchinin, p. 78). In the Canadian arctic, Brown and his associates (1975, p. 70) noted that snow ridge patterns, fonmed on the fast ice in fall, remainea intact throughout the winter. They noted the average depth of the snow on the fast ice by the end of winter was about $22 \mathrm{~cm}$, while at pruahoe Bay the tundra snow depth has been observed to average $32 \mathrm{~cm}$ (Benson and others, $1975)$

Oceanography

The oceanography of the fast-ice zone in winter is affected by the formation of an ice cover as well as by the presence of an ice cover. The process of freezing of sea water excludes brines so that the ice is of a much lower salinity than the waters from which it is formed. This has resulted in notable increases in the salinities of sub-ice waters in bays and lagoons where circulation is restricted (Schell, 1974, p. 240; Kovacs and Mellor, 1974, p. 117). Values of salinity in excess of $50^{\circ} / 00$ have been reported in these environments (schell, 1974). The presence of an ice cover dampens waves and renoves the influence of wind as a current driving force. Tidal currents generated by the $15-20 \mathrm{~cm}$ tides can be intensified in inlets by the decrease in cross sectional area due to ice growth. 
Previous work

The fact that snow depth influences ice thickness has beer known For some time (Zubov, 1943, p. 220). However, the magnitude of influence and the variability, have received minimal attention. Canadian studies of fast ice have shown that ice thickness is invexsely related to snow depth and that ice thickness varies by about 208 of the mean thickness (Brown and others 1975, p. 36). A $35 \mathrm{~cm}$ maximum difference in fast ice thickness at the end of the 1974-75 growth season was noted. Furthermore the snow drift pattern remained stable all winter once established in fall. These observations were then used to to develop heat transfer equations for ice, snow, and oil mixtures (Brown and others, 1975, p. 74).

Kovacs (1977) measured fast ice thicknesses along a IInear profile using electromagnetic techniques and found variabilities of $30 \mathrm{~cm}$ or about 25\% of the mean thickness (Kovacs, 1977, p. 548); but he did not relate this variability to snow cover. Kovacs (1977, p. 549) calculated potential volume of oil trapped in the voids on the undersurface of the ice (above his observed mean thickness) at $27,500 \mathrm{~m}^{3} / \mathrm{km}^{2}$.

Me thods

From 29 April to 15 May, 1978, field studies were undertaken in the Pruahoe bay area using a variety of techniques. At each of three sites a cross was staked out in the snow with one arm perpendicular to the dominant trend of surficial snow ridges. Each arm was $100 \mathrm{~m}$ Iong and intersected the cross am at $50 \mathrm{~m}$. After the cross was marked with Elags and stakes, snow depths were measured at $5 \mathrm{~m}$ intervals. Aerial photographs were taken from altitudes of 200 to $300 \mathrm{~m}$. Subseguentiy an 
access road was plowed to each site and the sea ice was cleared of snow for several meters on either side of the cross. A mechanical ditching machine was then used to cut a 20-cm-wide, 100-m-long trench through the ice along a transect corresponding to the cross initialiy marked in the snow. A $1.5 \mathrm{~m}^{2}$ block of ice was cut by the ditcher and lifted out with a fork lift to form a dive hole. The ditcher did not remove the bulk of the chips during trenching so that it was necessary to perform the tedious task of "mucking out" the trench and dive hole. The character of prepared sites is shown in Figure 1.

After the site had been clearea, a sled was propelied by hand over the trench. Sensors suspended from the sled - which also carried the electronics and recoxders--included upward-directed side-scanning sonar, precision fathometer, pressure transducers, and underwater television. Ice thickness and freeboard (water level to upper ice surface) were measured at $2-m$ intervals along the trenches. Sub-ice cemperature and salinities were measured with a conductivity bridge which has a temperature accuracy of $0.5^{\circ} \mathrm{C}$ and a salinity accuracy of $0.3^{\circ} / 00$.

A time lapse camera was mounted on a structure near the Arco west dock. The camera view was eastward, and exposures were obtained at 15 minute nominal intervals. Only two days of useable record were obtained--partly due to camera failure but primarily due to blowing snow or fog which obscured the camera view.

\section{Site Descriptions}

Three differing ice and oceanographic envizonments in the fast-ice zone were examined; one in the shallow, protected envizonment of prudhoe Bay; one in the deeper, open environment of stefansson sound; and one in a deep, narrow tidal inlet to Simpson Lagoon between Egg Islana and Long Island, as shown in Figure 2. 


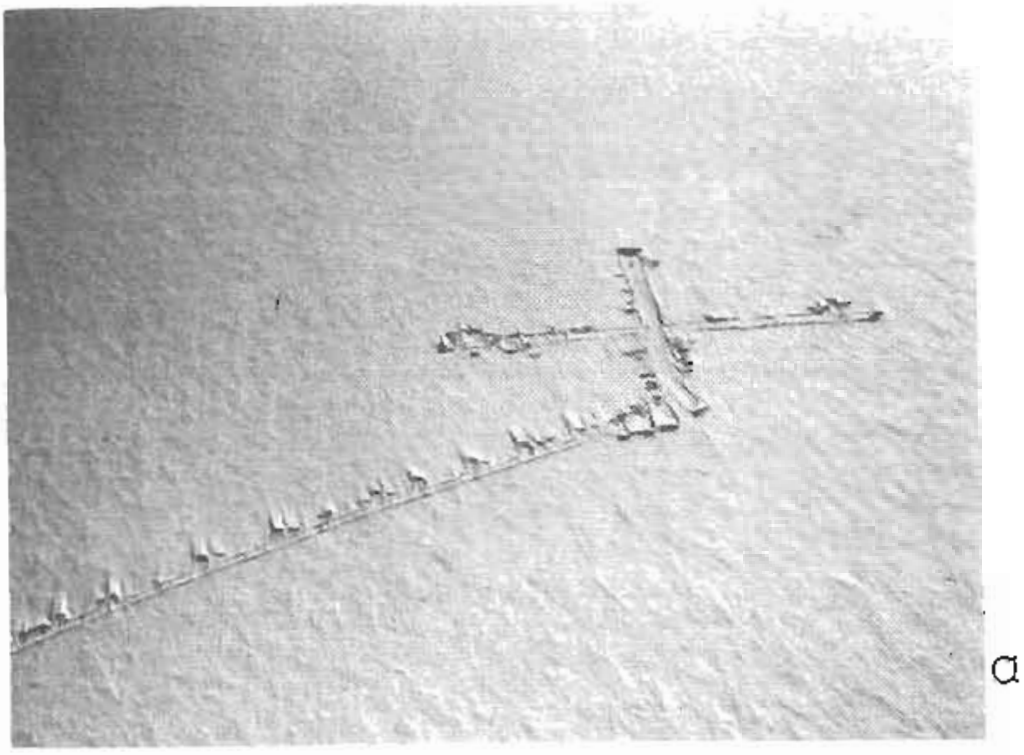

$c$

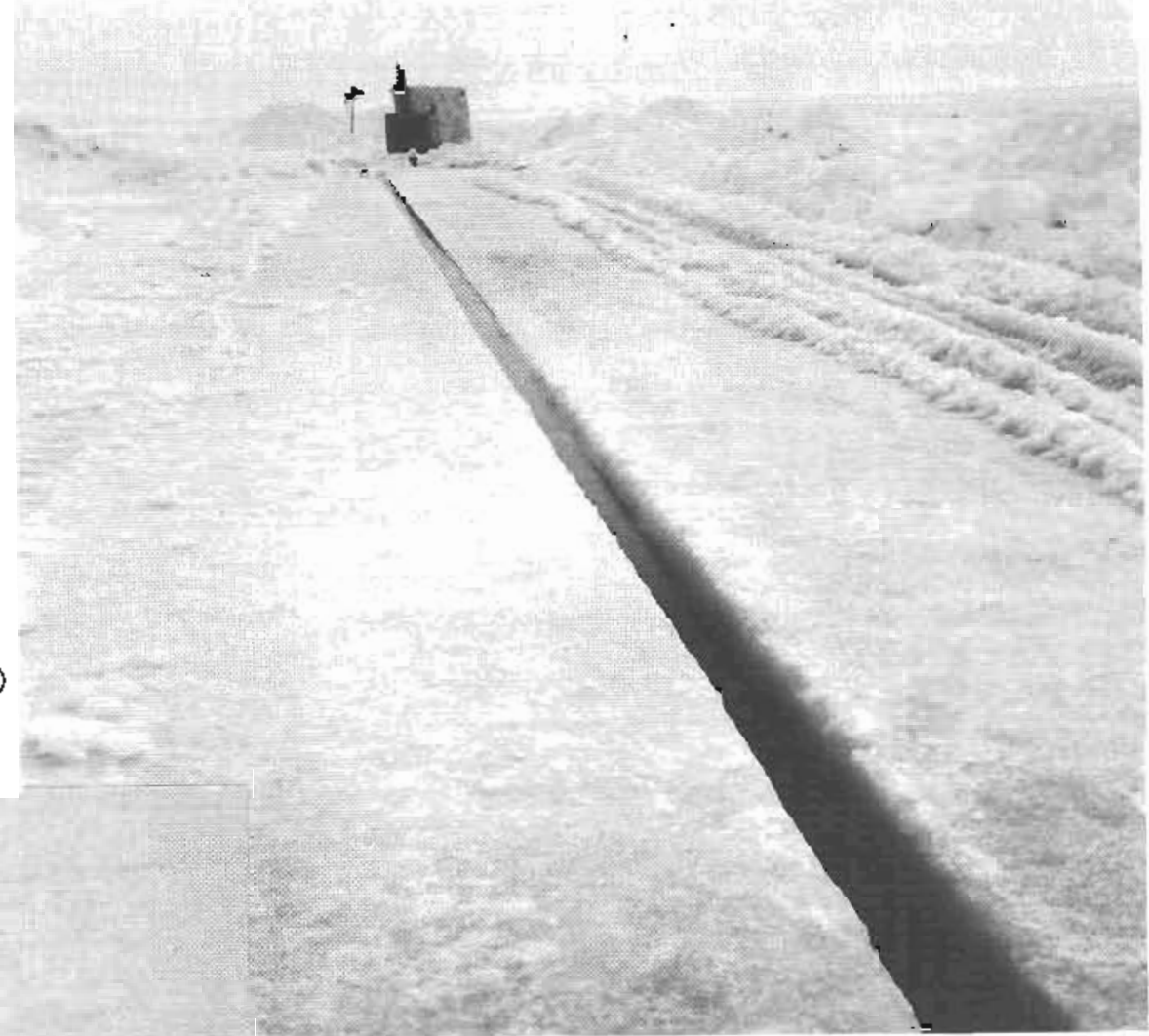

Figute 1. al derial plew or alce 1 snowng sne rast lce ana the access road ofter ald work was completed. Note the alignment of the cross with the elongate snow rldge pactern and tne drifts in the lee of snow plies. D) view along easterly arm of the cross at blte 1 showing the clean trench ano sea-ice surface. The large 1 ce block geen at the ena of the rrenco has been removed trom the ar ve nole. Note the varlablity in lce treeboard along the trench. C) Aerial view of site 3 gnowing the orientation and relation of the sxte to tne splt at the southerr tip of Long lstand (see fig. 2). Just to the right of the people near the center of the cross 1 one of the duve noles at this location. 


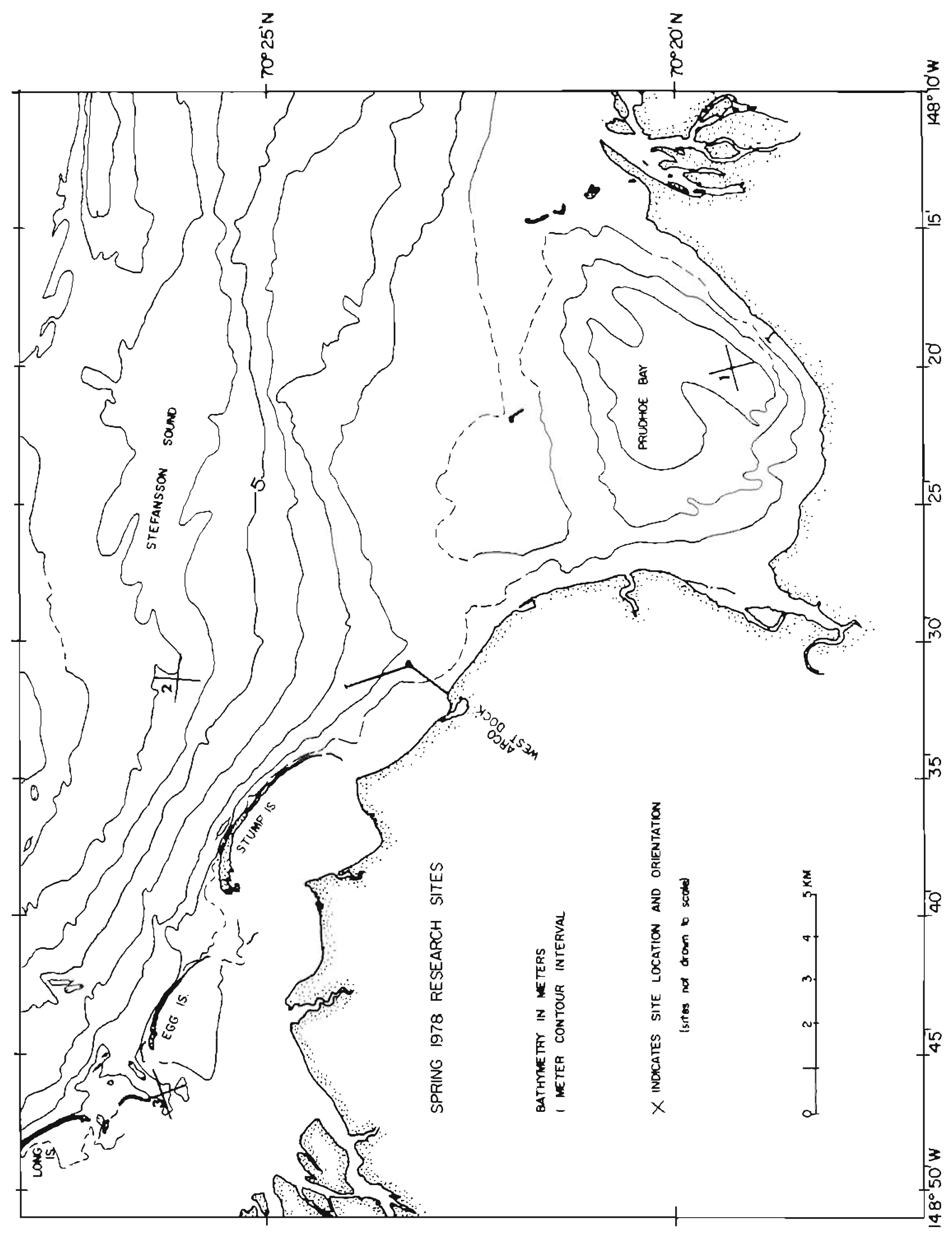


The Eruahoe Bay site (Site 1 ) is located in a semi-enclosed coastal embayment. Depths in the central part of the embayment approach $4 \mathrm{~m}$, although the deepest channel connecting the bay with the open ocean is less than $2 \mathrm{~m}$ deep (Barnes and others, 1977). Bay waters are free to communicate with the offshore oceanic environment during the summer, and is essentially oceanic in character at the time of freeze-up. Lateral ice motion within the bay is almost non-existent once a solid ice canopy has Eormed late in fall. With the formation of the ice canopy, circulation is restricted so that by the time of our field studies in spring, sub-ice waters were less than $-2^{\circ} \mathrm{C}$ in temperature and greater than $64^{\circ} / 00$ in salinity. At the time of our fieldwork the undersurface of the ice was less than $2 \mathrm{~m}$ Erom the sea bed and themal, brine drainage, tidal or current intensification influence on the sea bed due to ice was thought to be most pronounced. Vertical ice motions due to tidal interchange through the channel during winter, as proposed by Barnes and others (1977, p. 12), were not observed at a nearby ice level recording station. In summary, the pruohoe Bay site was characterized by high salinities, a close proximity of the under-ice surface to the sea bed, extremely weak sub-ice currents, and an absence of large lateral or vertical motions of the ice canopy. The stefansson Sound site (Site 2), with water depths greater than $5 \mathrm{~m}$, is a deeper, more opes environment than the Pruahoe Bay site. Iateral ice motion in stefansson sound prohably occurred during the early winter as evidenced by the blocky, irregular, and justaposed ice patches along the road plowed to the site. The sub-ice waters are free to communicate with the ocean throughout the winter and temperatures of 
$-2^{\circ} \mathrm{C}$ and salinities of $38^{\circ} / 00$ were recorted. In spring, 1972, we measured weak sub-ice currents towards the northwest at $2 \mathrm{~cm}$ per second or less at a station $7 \mathrm{~km}$ west of site 2 . In summary, at this site the ice canopy is well away from the influcnce of the botto:n and sub-ice water is calm with minimal currents. The lateral motion of ice during most of the ice growth season is insignificant, being protected by the island chain to the northeast.

The third site, between Egg Island and Long Island, (Site 3), represents a narrow, 5m deep, tldal channel between a shallow lagoon and the more open shelf. In spring, 1972, we neasured tidal currents of up to $20 \mathrm{~cm}$ per second in this channel (Fig. 3). During the present study, vertical ice motion of up to $20 \mathrm{~cm}$ with tidal period was recorded adjacent to this site, attesting to the interchange of lagoon and open ocean water areas whexe sub-ice currents are intensified and are known to reduce ice thickness (Zubov, 1943, p. 222). Observations at Site 3 in spring show the inlet to have open water earlier in the spring than elsewhere as show in Figure 4. Sub-ice waters were olvierved to be $-1.6^{\circ} \mathrm{C}$ and to have a salinity of $38^{\circ} / 00$, an increase of at least $10 \%$ over summer salinities (Barnes and others, 1977, P. A-9), perhaps representing brine drainage from the ice freezing process within the lagoon although these values were also observed at site 2. Lateral ice motion in the inlet is thought to be minimal although stresses are suggested by ice push onto the beach at the western edge of the site, and the numerous cracks up to $5 \mathrm{~cm}$ wide noted at the snow and ice surface. In surmary, this site is one where ice growth and sub-ice salinities could be influenced by a lagoonal jce canopy, where ice motion was expected to be mirimin, and where the effects of current were expected to be pronounced. 


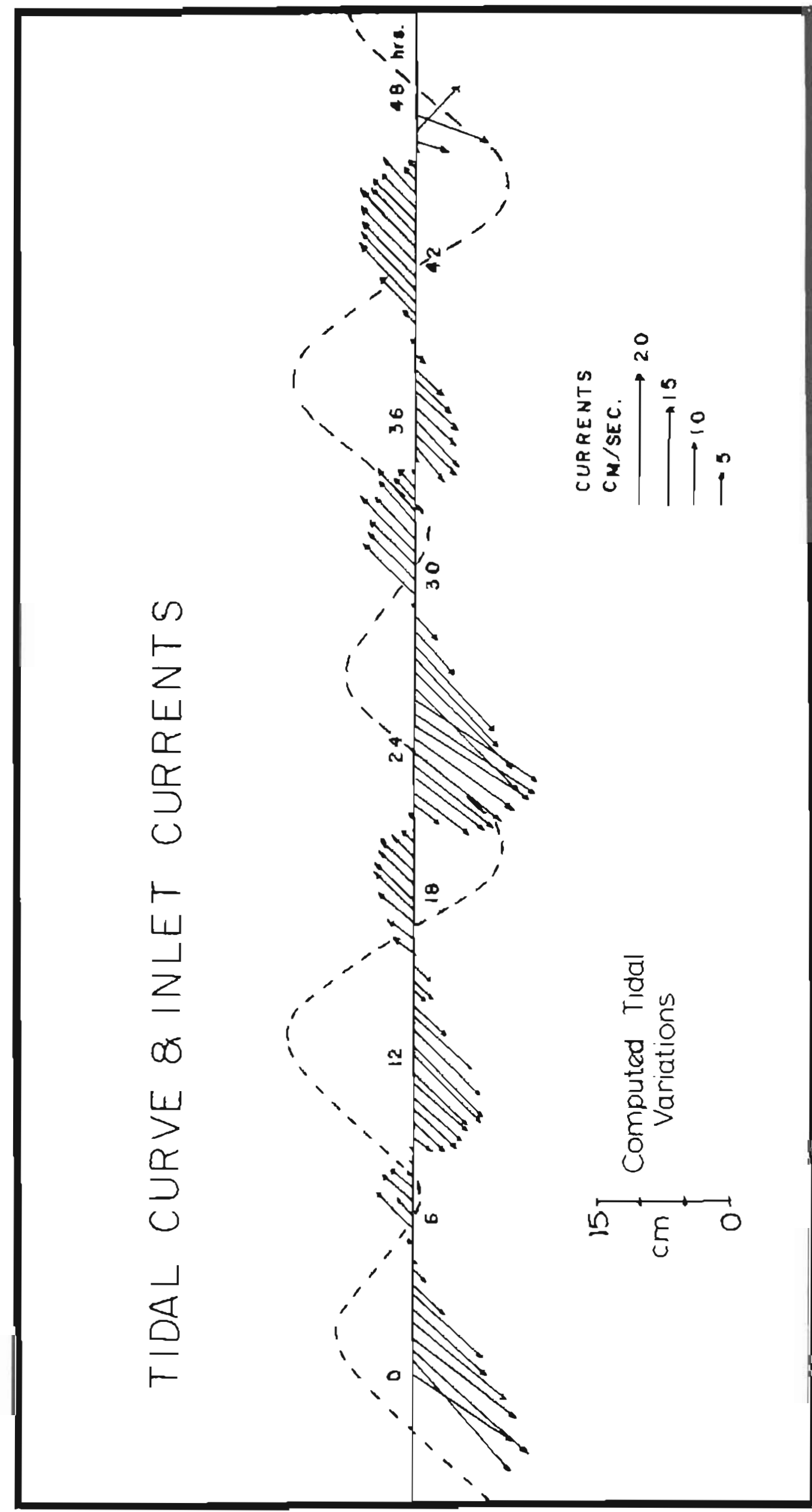

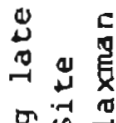

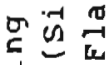

壳

\&

.

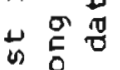

幽

\&

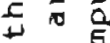

$3 \stackrel{0}{\circ}$

궁

H

ह5

0 \& a

in $c$ 音

0

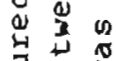

牙岁要

㟧

यन है

t.

\& $\rightarrow \pi$

मे 0

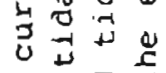

خ०

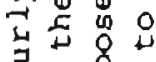

吃总

兵两

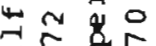

。合

- ज

变察六学$$
\dot{m}
$$

$\dot{m}$

हू 


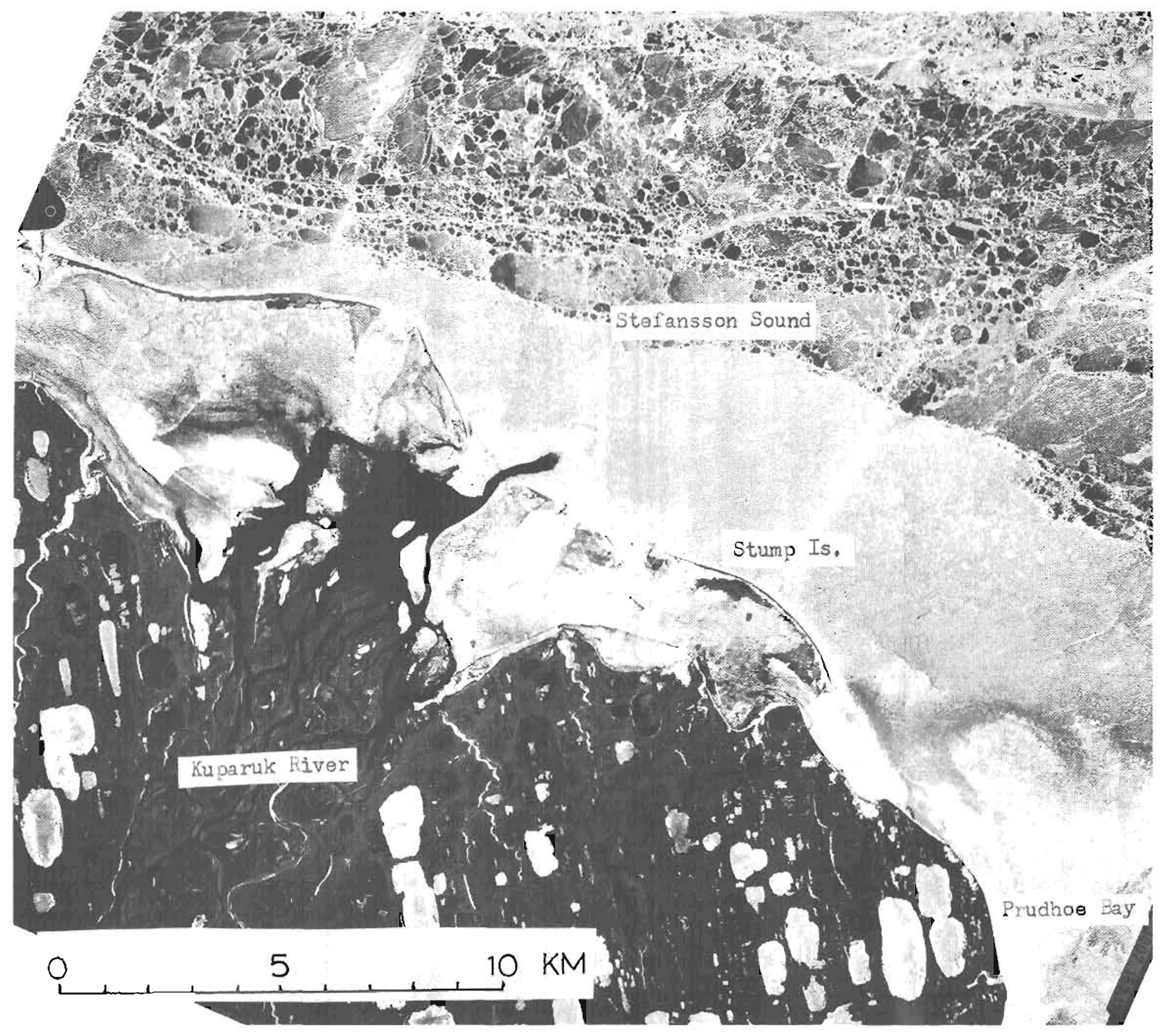

Figure 4. Aerial photograph of the coast and inner shelf just west of Prudhoe Bay taken in June, 1974. Ice is present offshore and in the lakes. Note the open water at the tidal inlet (site 3) and the uniform character of the ice nearshore in comparison to further offshore in stefansson sound. 
RESULTS

Correlation of Snow Depth and Ice Thickness

Reconstructions of snow depth, ice thickness, and ice freeboard

(aistance from the watex level to the ice surface) along the trenches illustrate the relationship of snow depth to ice thickness. Thin ice, Low Ereeboard, and deep snow are consistently related, both parallel to, and perpendicular to, the snow ridge pattern (Figure 5 and Table I.). Snow depths averaged 15 to $24 \mathrm{~cm}$ but ranged from $4 \mathrm{~cm}$ to $48 \mathrm{~cm}$ at the three study sites. Site 2 had on the average $10 \mathrm{~cm}$ less snow than other sites. The average, maximum, and minimum snow depths were similar on transects both perpendicular and parallel to the snow ridge pattern (Table I).

Ice thickness at the three study sites averaged between 134 cm and $157 \mathrm{cr}$ Lut ranged from $114 \mathrm{~cm}$ to $169 \mathrm{~cm}$. The ice was thinnest at site 1 but essemtially the same at sites 2 and 3 (Table I). In most case 5 the upper ice surface shows isostatic adjustment to thickness--less Freeboard is associated with thinner ice and deeper snow. Statistical consideration suggests that less range in both snow depth and ice thickness would be observed along transects parallel to the snow ridges than at right angles as fewer ridges and troughs would be encountered in the sample. Snow depth shows this relationship only at sites 1 and 3, although ice thickness shows a smaller range parallel to the snow pattern only at sites 1 and 2; but in both cases the differences are 308 or less.

As a test for snow depth-ice thickness correlation, graphs were ploted for total snow depth versus total ice thickness using data 


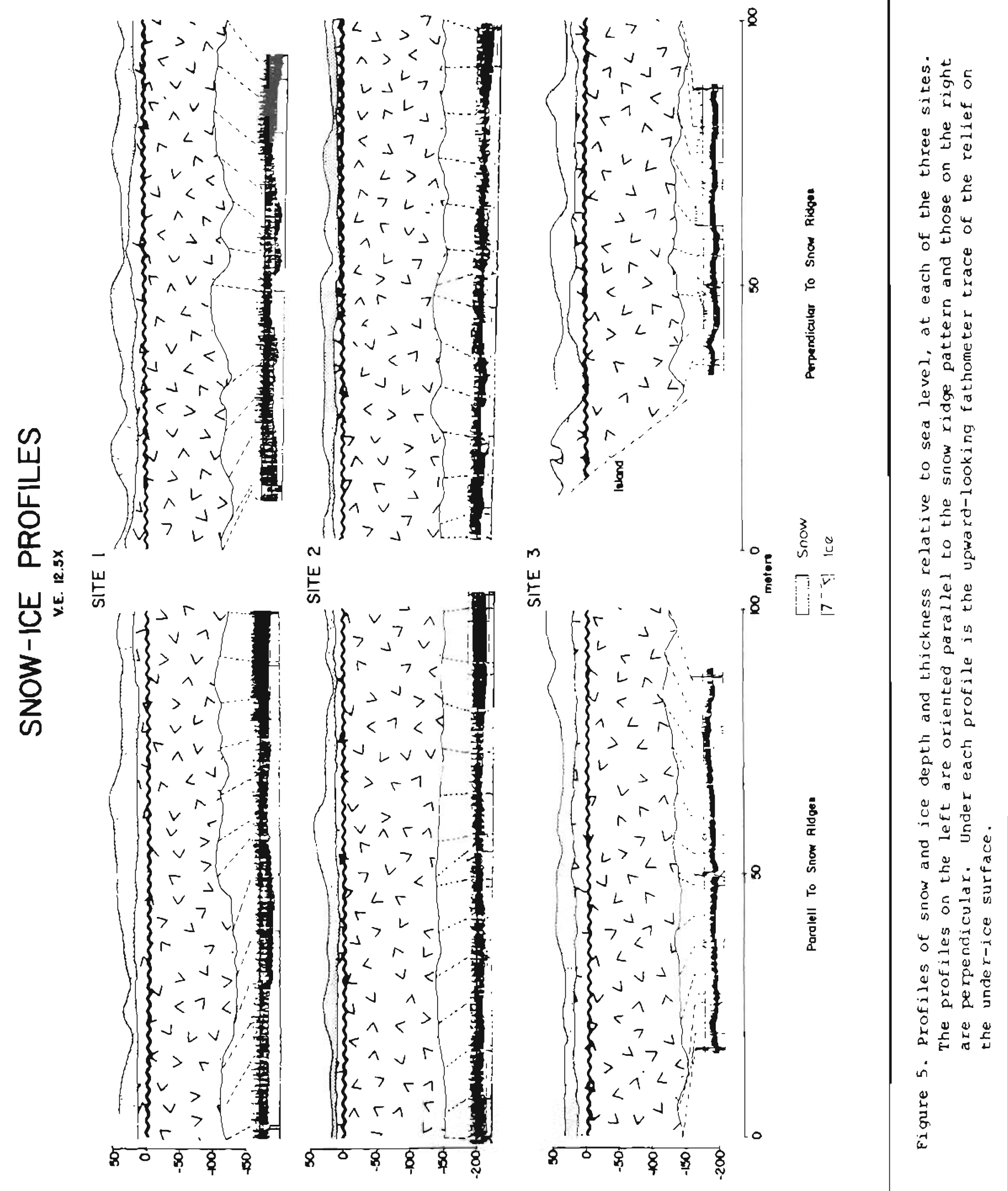




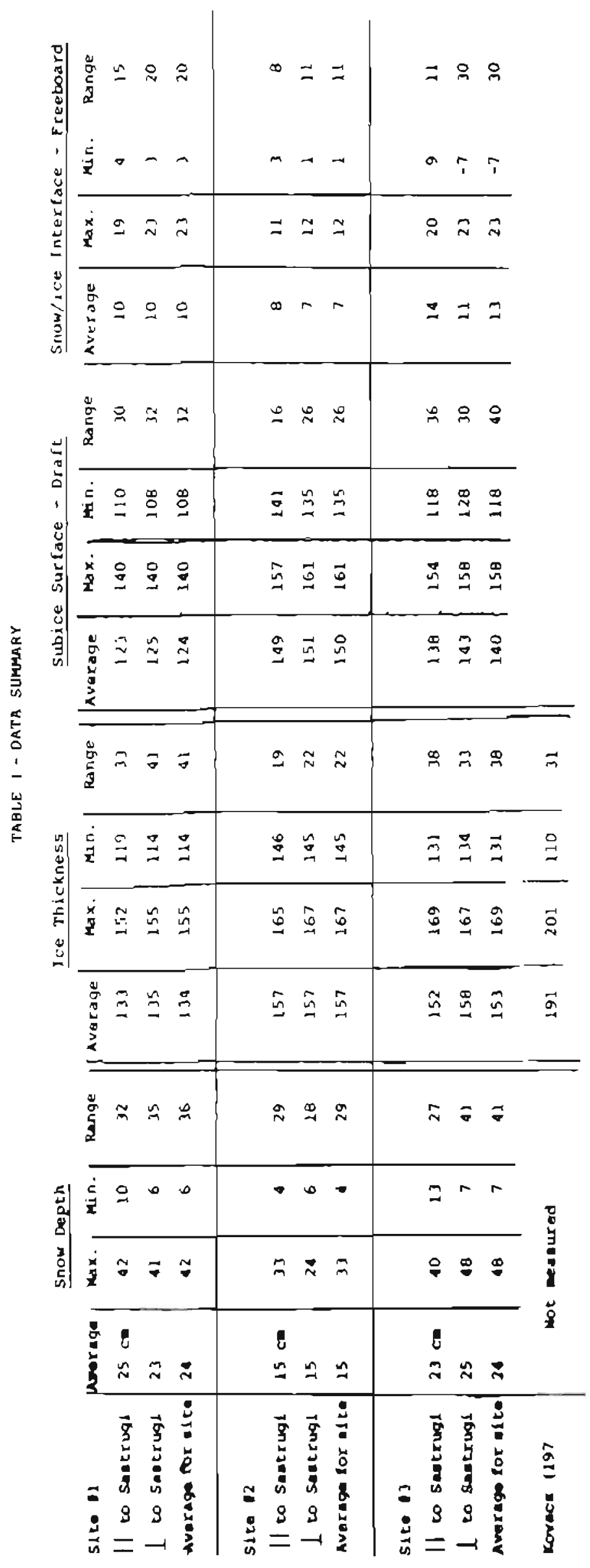


gathered at $5 \mathrm{~m}$ intervals. The data used for these graphs were then used to detemine a correlation coefficient between ice thickness and snow depth and the best fit line for the data at each site. At all three sites studied there was a negative correlation between ice thickness and snow depths measured along the trenches. The plots and the correlation coefficients show that a good correlation exists at sites 1 and 3. The correlation at site 2 is weaker as shown in Figure 6. Morphologic Comparison of Snow and Under-ice Surface The results show a good correlation between the morphologic pat tirns found on the snow surface and the morphologic patterns found on the? undersurface of the fast ice. The quality of side-scan records and at: iil photography were such that precise correlation feature for ind

The surface of the sea ice in the study areas was covered with snow in the form of ridges and txoughs which were scoured and eroded formilng sastrugi. The snow ridges and sastrugi showed an orientation of 70 degrees. Snow ridge wavelength, as observed in aerial photography, was typically $10 \mathrm{~m}$; although values ranged from $5 \mathrm{~m}$ to $20 \mathrm{~m}$. The character of the snow surface, as observed from aerial photography, is shown in Figure $7 \mathrm{a}$ and the interpreted ridge-crest pattern from this photography is shown in Figure ga.

side-scanning sonar records of sub-ice reflectors showed linear orientation of 70 degrees although the variability was greater than with the snow ridge orientations. Although the crests were less clearly defined on the sub-ice record than on the aerial photographs, wavelengths between crests were typically $1 \mathrm{c} \mathrm{m}$ and ranged from 5 to $18 \pi$ - similar to the snow surface character. A sonograph from test 


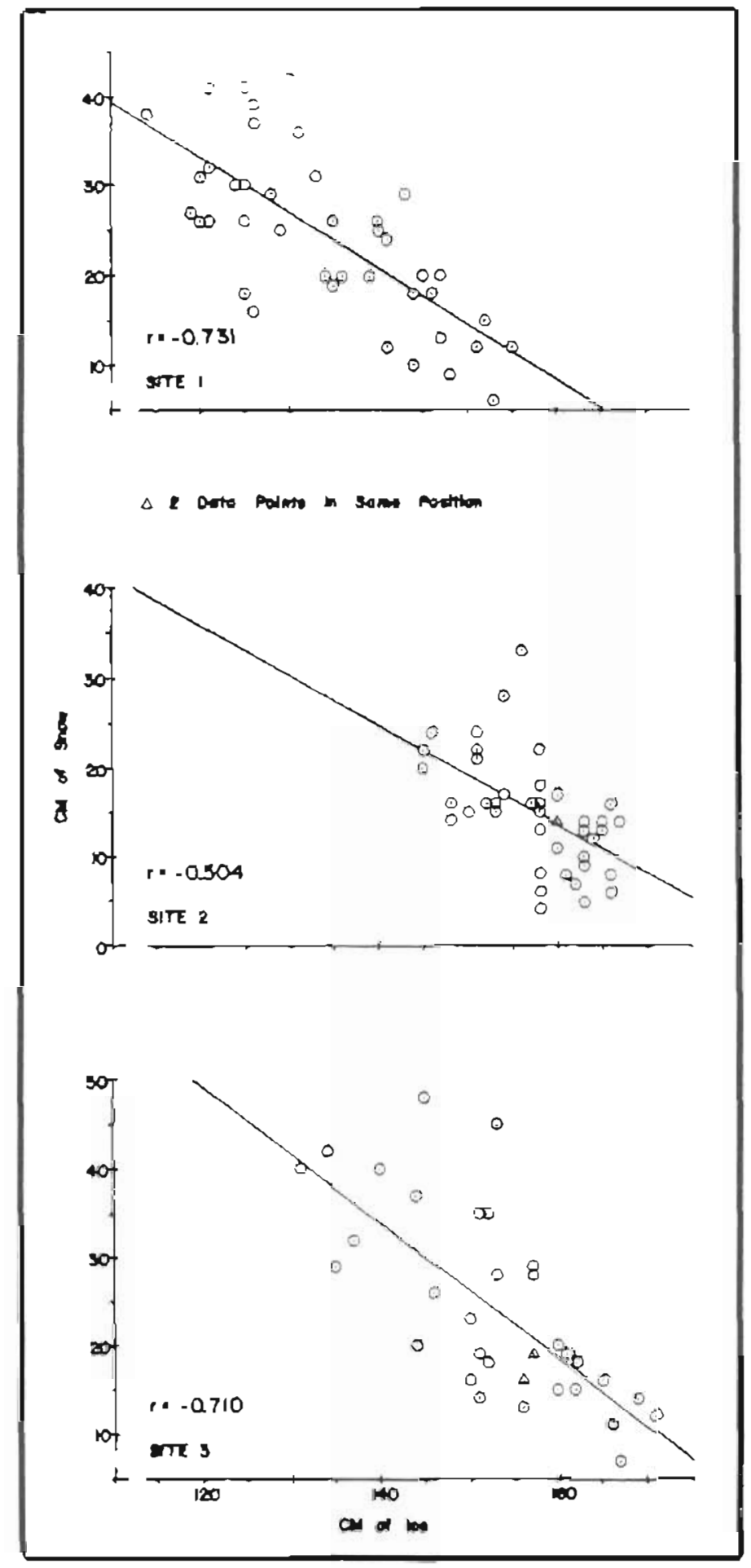

Figure 6. Scatter plots, best line fit and correlation coefficients for ice thickness and snow depth values at each of the three sites. 


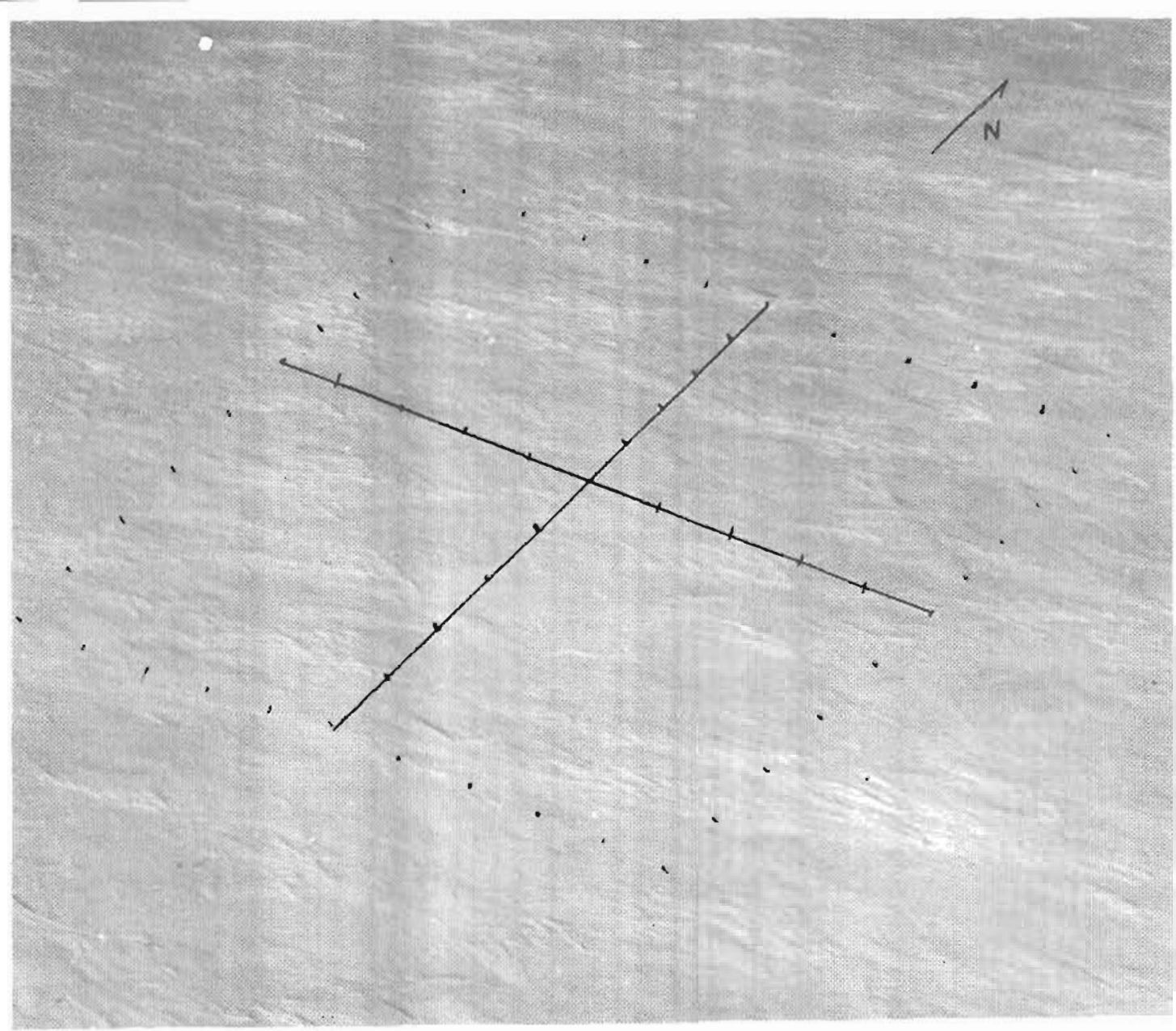

Figure 7a. Aerial photograph of site 2 prior to plowing and trenching, showing the snow ridge pattern. The $100 \mathrm{~m}^{2}$ grid and the cxoss have been added.

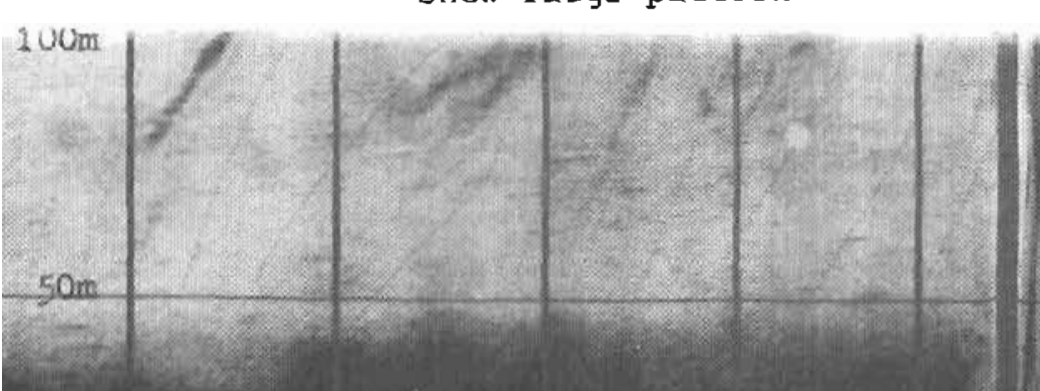




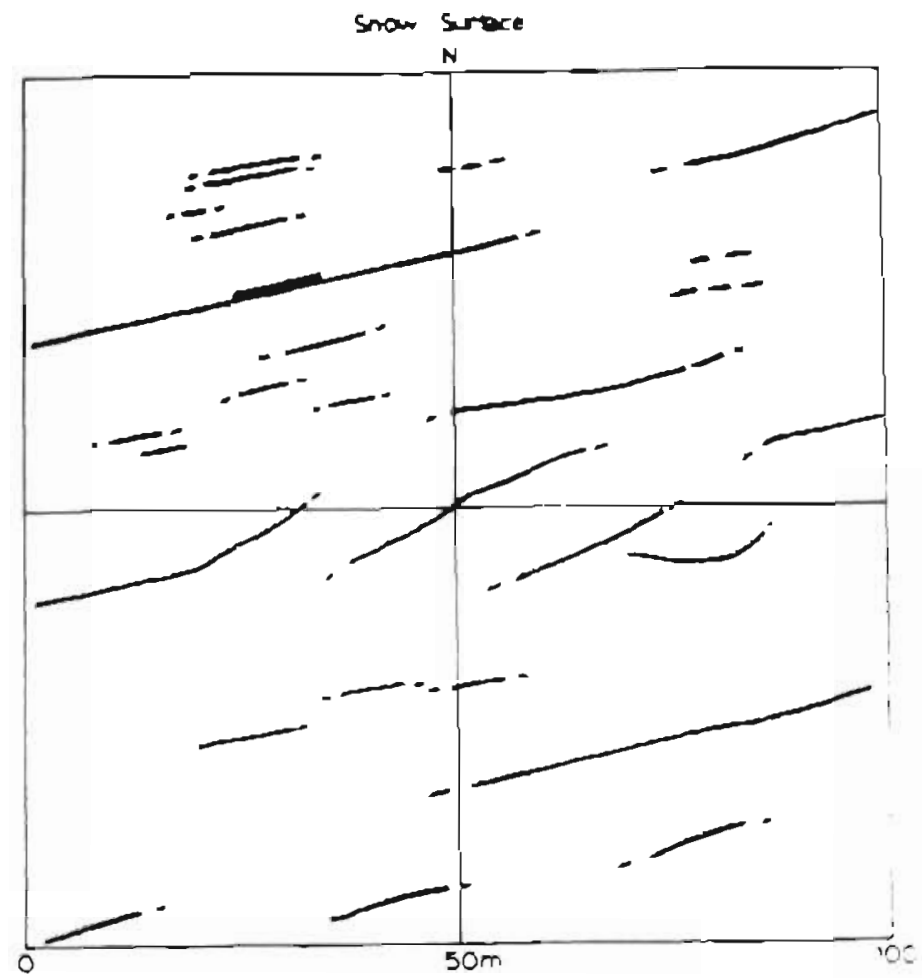

Figure 8a. Snow ridge pattern interpreted from the aerial photograph shown in Figure $7 a$.

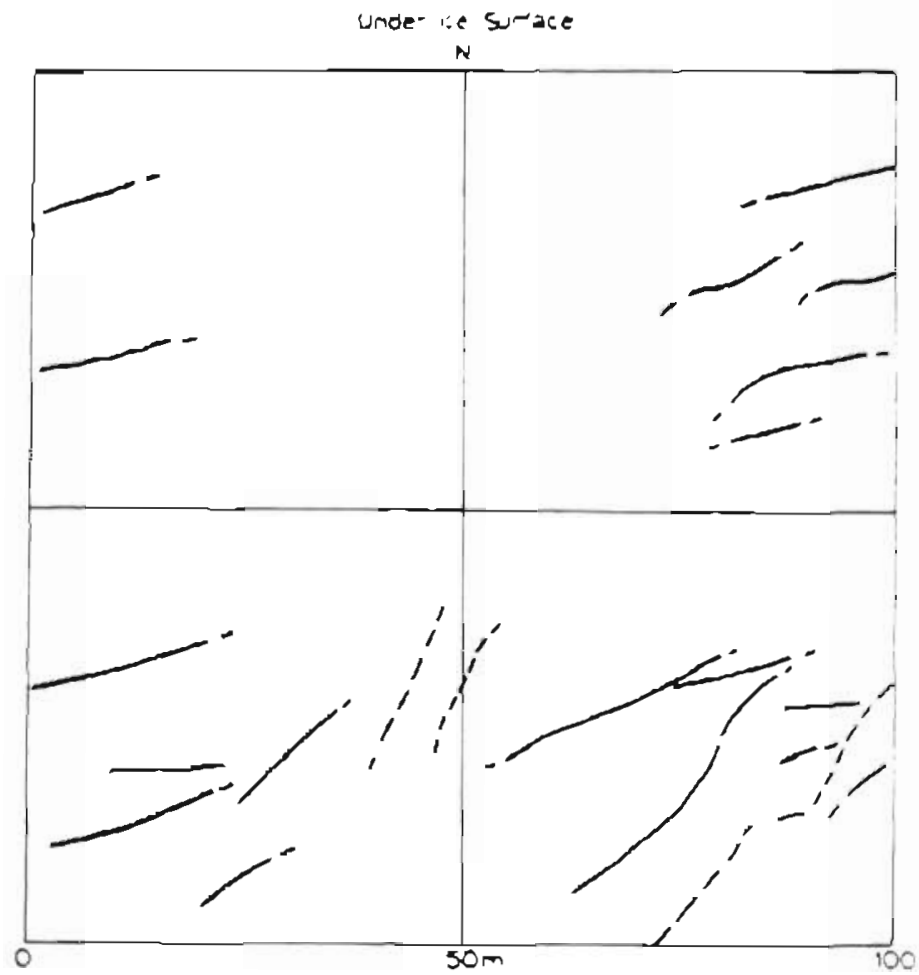

Figure 8b. Ridge pattern on the undersurface of the ice at site 2 interpreted from the oonographs of Fugure $7 b$. 
Site 2 showing the reflectors on the undersurface of the ice is shown in Figure $7 b$ and the interpreted crest orientation location is shown in Eigure $8 \mathrm{~b}$.

\section{Stability of snow Ridges}

Repetilive surveys and time lapse photography indicate that the basic ridge and trough snow pattern is stable. At sites 1 and 3 the snow depths along the cross were remeasured after a northeasterly wind redistributed much snow on the sea ice. During the interval between these measurements wind velocities were above $10 \mathrm{~m} / \mathrm{sec}(20 \mathrm{knts})$ and gusts in excess of $15 \mathrm{~m} / \mathrm{sec}(30 \mathrm{knts})$ were recorded at the Deadhorse airport for a period of 12 or more hours. Although these winds moved considerable snow, the profiles before and after the wind events at both test sites were essentially unchanged. Ridges and troughs avincilied before and after the wind events. Additionally, simple downind extension of snow ridges was not observed. The changes in snow depth as measured at sites 1 and 3 are illustrated in Figure 9 along with the wind data which show the wind events between the two surveys. The time lapse camera record illustrated transient snow movement events yet also attested to the stability of the snow ridges. On May 2nd, when wind velocities at the Deadhorse airport were in excess of $10 \mathrm{~m} / \mathrm{sec}(20 \mathrm{knts})$, the film showed snow spots of irregular outline and dxifts with a barchan-like form migrating downwind temporarily covering and uncovering stationary snow ridges. Between the 6 th of May and the $15 t h$ of May wind speeds in excess of $10 \mathrm{~m} / \mathrm{sec}(20 \mathrm{knts})$ were recorded and a similar movement of snow spots was observed although the barchanlike forms were less well developed; rather, ripple-like features transverse to the wind were developed. The sastrugi-sculptured snow ridges reatained essentially unchanged. 


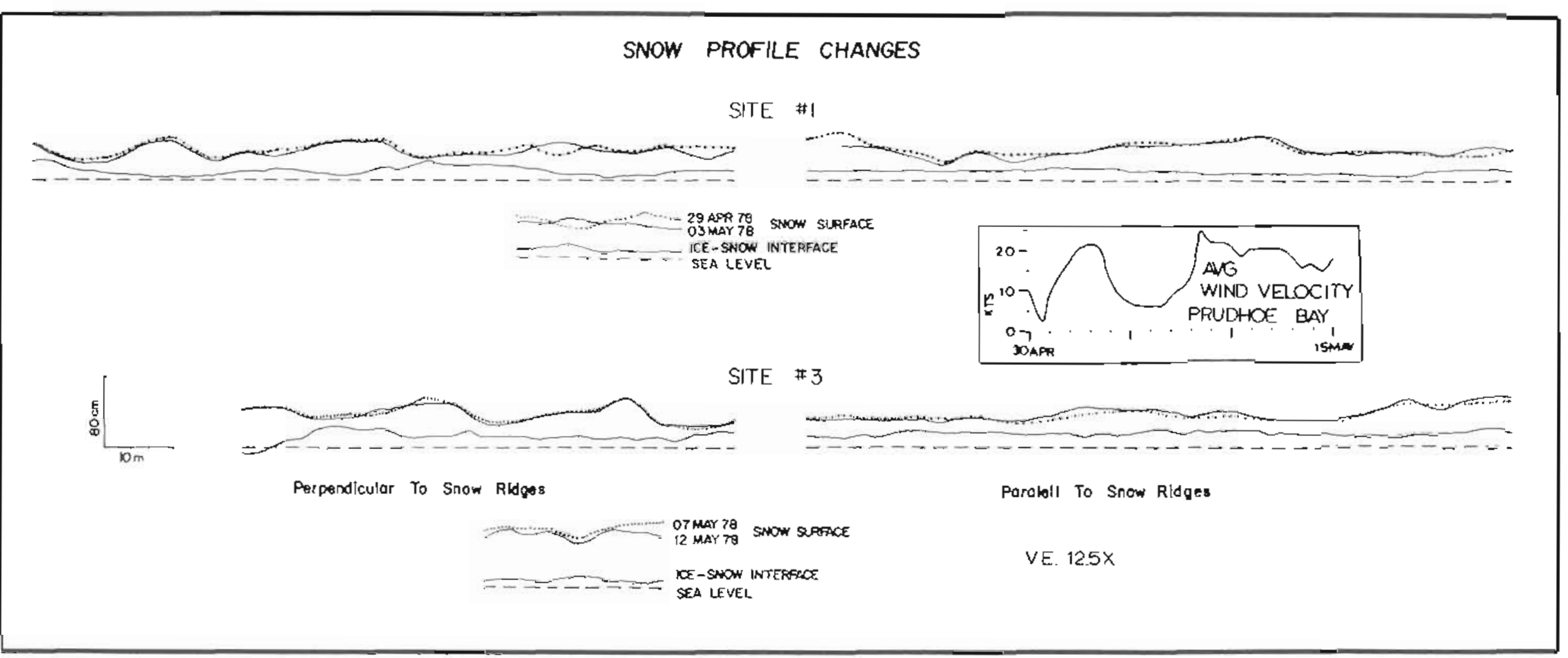

Figure 9. Replicate snow depth measurements at Sites 1 and 3 showing the small changes occurring during two wind events with velocities in excess of 20 knots. Wind data from the airport at prudhoe Bay is shown in the inset. 


\section{Diving Observations}

Diving observations on the undersurface of the ice were surprisingly similar at the three distinctly different environments. Observations were hampered by low light levels under the ice due to the large quantity of sediment included in the upper part of the ice canopy. The broad undulations seen by side-scan and upward-looking sonar are not visible to the eye, even with 5-10 m visibility. Smaller undulations, forming 5 to $8 \mathrm{~cm}$ deep diver-exhaust air pools, 2 to $6 \mathrm{~m}$ in diameter, were observable only because of the trapped air. The smallest air pools outlined $2 \times 10 \mathrm{~cm}$ long depressions that are about 0.5 to $1 \mathrm{~cm}$ deep, and oriented parallel to the ice crystal fabric. Undex proper lighting this fabric was distinct, and over aistances of 1 to $3 \mathrm{~m}$, parallel.

Randomly distributed ice stalactites, about $2 \mathrm{~m}$ apart, and $3 \mathrm{~cm}$ to $50 \mathrm{~cm}$ long were the most distinct sub-ice features. These stalactites consist of a very fragile crystal matrix. The large ones apparently have hollow cores. The stalactites mark brine channel openings from $0.5 \mathrm{~cm}$ to $8 \mathrm{~cm}$ in diameter (large enough to insert all four fingers of a gloved hand). One of the stalactites we observed closely was about $10 \mathrm{~cm}$ long and was actively spilling a plume of brine, 10 to $20 \mathrm{~cm} 10 \mathrm{~g}$, marked by light diffraction. The large stalactites resulted from the drainage of water we placed on the lce surface during trench-making activities. Under the prevailing conditions of open brine channels, our breath exhaust leaked through the fast ice very rapidly so that $3 \mathrm{~m}$ diameter, 5-8 cm deep air pools disappeared in several minutes while bubbling was observed on the ice surface as the air escaped.

In summary, our results show a strong correlation between measured 
In summary, our results show a strong correlation between measured snow deptn and lce thickness and a good correlation between the morphology as expressed by the orientation and the wavelength of snow ridges and under-ice surface relief. The observed stability of snow ridges indicates that the surface snow pattern is of prime importance in determining the morphology of the undersurfac: of the ice in several environments of the fast ice in the Prudhoe Bay area.

\section{DISCUSSION}

The correlation and charactor of snow and ice relief has implications regarding the stability of snow patterns, the potential for under-ice oil entrapment, and the physical differences between the different sites studied.

If snow ridges actively milfrte during winter, their insulating effect or the sea ice would be mitigated as they migrated across the surface, tending to smooth out heat transfer differences. Consequently differences in ice thicknesses would be less and unrelated to snow patterns. The correlation between ice thickress and snow depth, and similarities between surface snow patterns and under-ice relief suggest that the snow ridge and trough character is stable throughout most of the winter. This is contrary to the intuitive observation that the wind-faceted sastrugi and drifting snow indicate these bedfoms are in constant motion through the winter. Instead, it appears, as shown in our time-lapse photography, that snow spots and/or barchans are the mobile manifestation of a small segment of the snow cover at times of wind-driven snow events. Futhermore, it appears that the snow in transit does not affect the basic distribution of snow ridges and troughs. 
The snow-ice correlation also suggests that the intermittent

presence and movement of snow patches is apparently less important in the overall themal regime than the underlying snow ridge. The effect of moving snow patches may be to increase the average insulation effect on the sea ice. The data also suggest that the oriented snow ridges and troughs probably form early in the ice growth season to allow sufficient time for development of ice thickness variations. This also suggests. that northeasterly vinds are prevalent early in the season and maintain themselves as the dominant force throughout the winter (Aagaard, 1978 ). A variety of winds from other directions might. be expected to complicate the snow pattern and diffuse the correlation between ice thickness and snow depth.

An estimate was made of the potential for oil entrapment in the troughs on the undersurface of the fast ice. An assumption had to be made regarding the voids to be considered for this calculation. As oil reaches the unaersurface of the ice it will spread laterally, equalizing at some "depth" beneath the ice depending on the elevation of "passes" between adjoining ridges and troughs on the under-ice surface. Intuitively it seemed reasonable to assume that "passes" in the underice ridge and trough pattern would exist near the mean araft computed for the ice. Thus the voids detemined from our calculations are based on the relief above the computed mean araft at each site. our calculations differ from those done by Kovacs (1977) in that we use the araft variations of our ice rather than ice thickness to compute voids. Draft values take into account the isostatic effects and result in lower volume calculations. The results of these calculations show a considerable difference between the three sites but all sites have values of the same order of maqnitude $\left(25\right.$ to $\left.47 \times 10^{3} \mathrm{~m}^{3} / \mathrm{km}^{2}\right)$ yet are 
comparable to the values obtained by Kovacs in 1977 (Table II). Thj.s suggests that in the fast ice zones where ice is presumed to be flat, a considerable volume of oil could be contained on the undersurface of tilk fast ice in a rather small area (600 to 1200 barrels per acre). Each site appears to be a unique physical environment as was initially suggested when the reasons for choosing these sites was discussed. Site 1 showed a good correlation between snow depth and ic:r thickness and is believed to represent the stability of the ice in Prudhoe Bay. However, the average ice thickness and computed ice thickness were thinner at Prudhoe Bay than at the other two sites by about $20 \mathrm{~cm}$ (Table II), reflacting the fact that high sub-ice salinities resulted in lower freezing temperatures and a slower rate of ice growth than at the other sites.

The average snow depth at : itc 1 is l.he same as at site 3 but deeper than at site 2. On the tundra the average snow depth was noted by Berson and others $(1974, p .24)$ to be $32 \mathrm{~cm}$. Our sites closest to the tundra, sites 1 and 3 , show $24 \mathrm{~cm}$ average snow depth while our site furthest from shore, sice 2, shows only $15 \mathrm{~cm}$ of snow depth, implying a gradient of increasing snow depths in an onshore direction. This gradient is believed to result from the variabiluty of the terrain on which the snow is accumulating. A terrain with a great deal of relief would naturally accumilate a greater average snow depth due to the presence of larger traps, whereas a terrain of low relief would provide Iess obstruction to the flow of blown snow. Indeed this is what we observed, in that the observed range and freeboard is least at our offshore site, being about $10 \mathrm{~cm}$, while at the inshore sites the range is about $20 \mathrm{~cm}$. The relief on the tundro is even greater (Bensor and others, 1975). 
TABLE II

SITE COMPARISONS

\begin{tabular}{|c|c|c|c|c|c|c|c|c|}
\hline & $\begin{array}{l}\text { Snow Depth } \\
\text { Ice Thickness } \\
\text { correlation } \\
\text { coefficient }\end{array}$ & $\begin{array}{l}\text { Ice Thickness } \\
\text { Computed for } \\
\text { ' } 0 \text { ' Snow depth }\end{array}$ & $\begin{array}{l}\text { Observed } \\
\text { Average Ice } \\
\text { Thickress }\end{array}$ & $\begin{array}{l}\text { Observed } \\
\text { Average } \\
\text { Snow Depth }\end{array}$ & $\begin{array}{l}\text { Observed } \\
\text { Average } \\
\text { Freeboard }\end{array}$ & $\begin{array}{l}\text { Sub-ic } \\
\text { Temp. }\end{array}$ & $\begin{array}{l}\text { ce watex } \\
\text { Salinity }\end{array}$ & $\begin{array}{l}\text { Sub-ice Voids } \\
\text { Above Average } \\
\text { Draft }\end{array}$ \\
\hline $\begin{array}{l}\text { Site \# } 1 \\
\text { Prudhoe Bay }\end{array}$ & -0.73 & $173 \mathrm{~cm}$ & $134 \mathrm{~cm}$ & $24 \mathrm{~cm}$ & $10 \mathrm{~cm}$ & $<-2.0^{\circ} \mathrm{C}$ & $>64^{\circ} / 00$ & $\begin{array}{l}47,000 \mathrm{~m}^{3} / \mathrm{km}^{2} \\
\text { (12 } 00 \mathrm{bbls} / \text { acre }\end{array}$ \\
\hline $\begin{array}{l}\text { Site \# } 2 \\
\text { Stefansson sound }\end{array}$ & -0.50 & $184 \mathrm{~cm}$ & $157 \mathrm{~cm}$ & $15 \mathrm{~cm}$ & $7 \mathrm{~cm}$ & $-2.0^{\circ} \mathrm{C}$ & $38^{\circ} / 00^{a}$ & $\begin{array}{l}25,400 \mathrm{~m}^{3} / \mathrm{km}^{2} \\
(650 \mathrm{bbls} / \mathrm{acre})\end{array}$ \\
\hline $\begin{array}{l}\text { Site } \# \\
\text { sidal Inlet }\end{array}$ & -0.71 & $184 \mathrm{~cm}$ & $153 \mathrm{~cm}$ & $24 \mathrm{~cm}$ & $13 \mathrm{~cm}$ & $-1.6^{\circ} \mathrm{C}$ & $38^{\circ} / 00$ & $\begin{array}{l}36,200 \mathrm{~m}^{3} / \mathrm{km}^{2} \\
(920 \mathrm{bbls} / \mathrm{acre})\end{array}$ \\
\hline Kovacs, 1977 & & & $190 \mathrm{~cm}$ & & & & & $27,500 \mathrm{~m}^{3} / \mathrm{km}^{2}$ \\
\hline
\end{tabular}

a) measured $15 \mathrm{~km}$ to $\mathrm{E}$ in Stefansson Sound 
At Site 2 there is a weaker correlation between ice thickness and snow depth as compared with the other two sites. Furthermore, this site has the smallest value for sub-ice voids. We suggest that ice motion probably occurred here early in the ice growth season. Even a small rotation could cause snow patterns to be realigned and new areas of greater or lesser insulation to develop, thus mitigating some of the early season thickness variations. As a result, late season correlations of ice thickness and snow depth would not be as well devloped.

Site 3 is characterized by a good correlation between snow depth and ice thickness and by an extreme variation in freeboard. The snow depth-ice thickness correlation suggests strongly that currents are less efrective in controlling ice thickness than is the insulation effect of snow. It is interesting to note this conclusion in light of the recent work by kovacs and others (1978), which shows a strong relationship between ice crystal orientation and sub-ice current directions. Evidently there is no strong correlation between ice thickness, underice relief and crystal orientation. The $30 \mathrm{~cm}$ range in freeboara, Erom $23 \mathrm{~cm}$ above water level to $7 \mathrm{~cm}$ below, suggests that the ice in this tia?. inlet may be under stress from motion early in the growth period or from stresses developed during the growth of the ice canopy due to confinement between the islands.

The geologic implications of the surface snow pattern and its stability and the resulting under-ice surface ridge and trough morphology are minor. Reimnitz and others (1978), have described windblown sediment accumulations that occur only in the upper parts of 
the snow on the fast lce. In light of the stability of the snow ridge and trough topography, eolian materia?. would be found only on the upper surface of the more stable snow ridges and associated with snow spots. Toimil and Reimnits, (1978), show a pattern of herringbone reflectors on side-scanning records which they ascribe to helical flow. The transverse wavelaniti of these features is about $10 \mathrm{~m}$ which corresponds to the $10 \mathrm{~m}$ wivelength between ridges on the undersurface of the ice. This ridge and 1 rough system may be responsible for the spacing ano the origination of the helical flow, whatever the source of current.

\section{Implications for of Eshore Development}

Several implications become apparent for ice management in an offshore development situation. Ice thickness can be controlled by varying snow depth. Maintenance of a snow-free ring around the development site could cause ice to grow thicker and obstruct outward flow of oil. If the removed snow were piled deeper on an inner ring, the ice would be insulated, decreasing ice growth, and causing a natural ring-shaped pocket to form on the undr.rsurface of the yce and floating sub-ice oil would gather inside of the thicker ice ridye. If an ice spill occurred in a natural snow and ice ervironment, accumulations of oil would be great under snow ridges. As these ridges will have the thinnest ice and the greatest accumulation of oil, a logical approach to clean-up might be to drill holes in the snow ridges. Adaitionally, the data suggest that the preaminant airection of oil migration would parallel the surface snow-ridge pattern. One woura not expect a circular oil sprich but rather a more elongate oil spread paralleling the surface snow pattern. 


\section{REFERENCES}

Aagaard, K., 1978, Physical oceanography and meterorology, in Weller, G., Norton, D., and Johnson, T, eds., Interim Synthesis Report: Beaufort/Chukchi Sea Environment, National Oceanic and̄ Atmospheric Adm., Boulder, CO, p. 56-100.

Barnes, P.W., Reimnitz, Erk, and Smith, Greg, 1977, Some coastal oceanographic observations--Beaufort Sea, Alaska, U.S. Geol. Survey Open-File Rept. $77-477$, P. A.1-9.

Benson, C.S., Holmgren, B., Trabant, D., and weller, G., 1974, Physical characteristics of seasonal snow cover in northern Alaska, Proc. of the Western. Snow Conference, 1974, University of Alaska, Fairbanks, Alaska, p. $58-63$.

Benson, C.S., Timmer, F., Parrish, S., and Holmgren, 5., 1975, Observations on the seasonal snow cover of Prudhoe Ray, Alaska during 1972, in Brown, J., ed., Ecological Investigations of the Tundra Biome in the Frudhoe Bay Region, Alaska, Biological Papers of the University of Alaska, Special Rept. 2, p. 13-5.

Brown, F.F., Dickens, E.F., and overal.1, J.G., 1975, The interaction of crude ojl with arctic sea ice, Beaufort sea Technical Report no. 27, Beaufort Sea Project, Dept. of the Enviroment, Victoria, B.C., Canada, 149 p. Kovacs, A., 1977, Sea ice thickness profiling and under-ice oil. entrapment, offshore Technology Conference Proc., v. 3, p. 547-554. Kovacs, A., and Mellor, M., 1974. Sea ice morphology and ice as a geologic agent in the southern Beaufort: Seed, in Reed, J., and Sater., J., eds., The Coast and Shelf of the Beaufort Sea, Arctic Inst. of North Mmerica, Arlington, Va., p. 113-161. 
Kruchinin, Y.A., 1962, Microrelief of the snow surface on the Lazerev ice shelE, Soviet Antarctic Expedition Information Bull., v. 4 (2), p. $77-79$.

Schell, D.M., 1974, Seasonal variation in the nutrient chemistry and conservative constituents in coastal Alaskan Beaufort sea waters, University of Alaska Institute of Marine Science, Rept. R74-1, p. $217-281$

Toimil, L.J., and Reimnitz, Erk, 1977, A Herringbone pattern of possible Taylor-Gortler-type flow orlgin son in sonographs, U.S. Geol. Survey Open-File Rept. no. 77-477, p. D-1.

Zubov, N.N., 1943, Arctic Ice, Translated by Naval Oceanographic Cifice and American Meteorological Society, 1963, pub. Naval Electronics Laboratory, San Diego, Ca., $491 \mathrm{p}$. 